Reprod. Nutr. Dévelop., 1980, 20 (5 A), 1527-1537.

\title{
Ribonucleic acid metabolism during planarian regeneration
}

\author{
par Isabelle MARTELLY, A. LE MOIGNE \\ Laboratoire de Biologie Animale, \\ U. E. R. de Sciences, Université Paris Val de Marne \\ Avenue du Général de Gaulle, 94010 Créteil Cedex, France.
}

Summary. A method for the extraction of total RNA of the planarian Polycelis tenuis is described. This technique has been applied to the study of RNA synthesis in the course of regeneration. Synthesis of RNA begins $7 \mathrm{hrs}$ after sectioning and proceeds in two phases. The first phase, from 7 to $21 \mathrm{hr}$ is characterized by an increased rate of $\left({ }^{3} \mathrm{H}\right)$ orotic acid incorporation into RNA up to the 18th after sectioning followed by a decrease between 18 and $21 \mathrm{hrs}$. The rate of precursor incorporation then rised again in the second phase to the 30th $\mathrm{hr}$ and finally decreased slowly until completion of regeneration. Studies of the pool of nucleotide precursors, show that the observed variations of orotic acid incorporation into RNA reflect variations in RNA synthesis.

Electrophoretic analysis of RNA labelled for 2 hrs at various times during regeneration shows that the product formed during the first phase of regeneration is mainly rRNA and low molecular weight RNA. The second phase of the regeneration process, from the 24th $\mathrm{hr}$, is characterized by the appearance of both ribosomal and polydisperse RNAs. These heterogeneous RNA species are detected up to the 46th hr of regeneration, after which time rRNA again becomes predominent.

The significance of the two phases of RNA metabolism of which this is the first observation during planarian regeneration is discussed in connection with other biochemical events which have been described during regeneration processes in planarians and other animals.

\section{Introduction.}

Although the morphological and the cytological aspects of the regeneration process of fresh water planarians are well documented (Morita et al., 1969 ; Sauzin, 1967 $a$ and $b$; Sauzin-Monnot, 1973 ; Spiegelman and Dudley, 1973), few studies have been made of the biochemical mechanisms involved in the regeneration process (Brondsted, 1969 ; Gabriel, 1969 ; Stewart ef al., 1968 ; Franquinef and Le Moigne, 1979). Several results however suggest that the crucial biochemical and cellular events which prepare the differentiation of the blastema take place within the first $48 \mathrm{hrs}$ following sectioning. For exemple, a blastema isolated at the 48th $\mathrm{hr}$ after sectioning can differentiate in an in vitro culture (Sengel, 1960) and neither X-ray irradiation (Gabriel, 1968a) nor an inhibitor of RNA synthesis such as actinomycin D (Le Moigne and Martelly, 1974) have an effect on the regeneration process when applied after the second day of regeneration. These results led us to focus our attention on the early biochemical events occurring at the onset of regeneration 
and in particular on the metabolism of nucleic acids. In the present paper we analyse the quantitative variations of RNA synthesis during the regeneration of adult planarians.

\section{Materials and methods.}

Animals. - Adult planarians of the species Polycelis tenuis starved for one week were kept in tap-water at $18^{\circ} \mathrm{C}$. They were cut into six equal pieces and the fragments regenerated during the stated times.

Origin of the products. - All isotopicaly labeled compounds were supplied by the CEA (Saclay, France), the scintillation liquid was provided by Packard. Tri iso-propylnaphthalen sulfonic acid (TNS) was purchased from Eastman, diethylpyrocarbonate from Schuchardt Müchen ; nucleotides, arotic acid and uridine came from Sigma, PEl cellulose sheets from Merck.

Labeling of RNA. - Preliminary experiments showed that labeled orotic acid was more efficiently incorparated into planarian RNA than uridine. Two hours before the end of the choosen regeneration time, sectioned animals were pulsed with tapwater containing $50 \mu \mathrm{Ci} / \mathrm{ml}$ of $\left({ }^{3} \mathrm{H}\right)$ orotic acid (sp. act. $25 \mathrm{Ci} / \mathrm{mM}$ ). All experiments included control incubations in which intact planarians were labeled separately under the same conditions. After incubation with $\left({ }^{3} \mathrm{H}\right)$ orotic acid, planarians were extensively washed and RNA extraction commenced.

RNA extraction. - Glassware were heated at $200^{\circ} \mathrm{C}$ for $2 \mathrm{hrs}$ and buffers were treated with diethylpyrocarbonate at $60^{\circ} \mathrm{C}$ for $1 \mathrm{hr}$ before use. Homogenization of planarians was carried at room temperature for $10 \mathrm{~min}$ in a glass-teflon homogenizer in $50 \mathrm{mM}$ Tris, $150 \mathrm{mM} \mathrm{NaCl}, \mathrm{pH} 9.0$ containing 2 p. 100 TNS ( $1 \mathrm{ml}$ per planarian) ; $\mathrm{pH} 9.0$ was chosen for quantitative extraction of RNA including mRNA (Brawerman, 1973). One volume of freshly distilled phenol was then added, allowed after $10 \mathrm{~min}$. shaking, by an additional volume of chloroformioamyl alcohol (24:1). After shaking for a further $10 \mathrm{~min}$ the phases were separated by centrifugation (15000 g) for $5 \mathrm{~min}$ and the phenolic phase was removed. The remaining aqueous phase and interphase were reextracted twice by the same procedure and once with chloroformisoamyl alcohol alone. The final aqueous phase was adjusted to a concentration of $300 \mathrm{mM} \mathrm{Na}$-acetate and precipitated overnight with 2.5 volumes of cold ethanol at $-20^{\circ} \mathrm{C}$. Precipitated nucleic acids were dissolved and precipitated at least twice from $100 \mathrm{mM} \mathrm{Na}$-acetate, $1 \mathrm{mM} \mathrm{Mg}$-acetate pH. 5.0 containing 0.5 p. 100 SDS in order to eliminate the remaining phenol. The crude product was dissolved in $10 \mathrm{mM}$ Tris$\mathrm{HCl}, 100 \mathrm{mM} \mathrm{NaCl}, 30 \mathrm{mM} \mathrm{MgCl} 2 \mathrm{pH} 7.0$ and the solution was incubated for $30 \mathrm{~min}$ at $5^{\circ} \mathrm{C}$ after addition of RNase free DNase $(10 \mu \mathrm{g} / \mathrm{ml})$ in order to remove DNA which represented about 13 p. 100 of the extracted nucleic acids. RNA was then recovered by precipitation with ethanol as before, assayed by spectrophotometry $(1 \mathrm{~A}$ $260 \mathrm{~nm}=41 \mu \mathrm{g}$ RNA), and stored at $-20^{\circ} \mathrm{C}$ in ethanol for at most 8 days before analysis by polyacrylamide gel electrophoresis. The extraction procedure described here yieled 25 to $40 \mu \mathrm{g}$ of RNA per animal, fresh weight 10 to $12 \mathrm{mg}$, depending on the duration of regeration. This amount was estimated to be slightly more than that extracted by Gabriel from lyophilised planarians (Gabriel, 1969). Extraction of given quan- 
tities of $E$. coli ribosomal RNA (given by $\mathrm{Dr}$ Grienenberger) were routinely performed simultaneously with planarian samples. The RNA recovery attained 85 p. 100 of the input RNA estimated by OD measurement before or after electrophoresis on polyacrylamide gels.

Electrophoresis on polyacrylamide gels. - RNA samples were electrophoresed in 2.5 p. $100(\mathrm{w} / \mathrm{v})$ polyacrylamide gels by a modification of the technique of Loening (1967). Electrophoresis buffer contained $0.1 \mathrm{mM}$ EDTA, $2 \mathrm{mM} \mathrm{Mg-acetate,} 30 \mathrm{mM} \mathrm{Na}$ acetate, $40 \mathrm{mM} \mathrm{Tris-} \mathrm{HCl} \mathrm{pH} 7.4$ and $0.5 \mathrm{p} .100$ SDS. Gels $/ 10 \mathrm{~cm} \times 0.7 \mathrm{~cm}$ ) polymerised in plexiglass tubes were prerun for one $\mathrm{hr}$ at room temperature and electrophoresis of the RNA samples was then performed for $2.5 \mathrm{hrs}(5 \mathrm{~mA} / \mathrm{gel}, 8 \mathrm{~V} / \mathrm{cm})$. The gels were then scanned with a densitometer (Joyce-Loebl) at $257 \mathrm{~nm}$ and cut into $2 \mathrm{~mm}$ slices. After treatment of each slice with hydrogen peroxide $\left(30\right.$ p. 100) for $6 \mathrm{hrs}$ at $60^{\circ} \mathrm{C}$, radioactivity was determined following addition of $10 \mathrm{ml}$ of scintillation liquid (Instagel). The correspondance between radioactivity and the profile of optical density was established by ink markers.

Determination of the molecular weight of RNA. - The molecular weights of the various RNA species were determined graphically using ribosomal RNA of E. coli (16 S and $23 \mathrm{~S}$ ) as standard (Bishop ef al., 1967). The molecular weights or rRNA from $E$. Coli were taken as $1.07 \times 10^{6}$ and $0.56 \times 10^{6}$ daltons (Stanley and Bock, 1965).

Nucleotide pool determination. - A double labelling technique was used (Horisberger and Amos, 1970). Planarians were labeled with $\left({ }^{14} \mathrm{C}\right)$ orotic acid $(7.4 \mu \mathrm{Cl} / \mathrm{ml}$, $45 \mathrm{mCi} / \mathrm{mM}$ ) for $30 \mathrm{hrs}$, rinsed in tap-water and groups of 10 animals were then sectioned. The fragments were allowed to regenerate in water for 16,19 or $21 \mathrm{hrs}$ and a $2 \mathrm{hr}$-pulse of $\left({ }^{3} \mathrm{H}\right)$ orotic acid $(40 \mu \mathrm{Ci} / \mathrm{ml}, 25 \mathrm{Ci} / \mathrm{mM})$ was then applied. Intact planarians were submitted to the same treatment. After exhaustive washing to stop labelling, animals were rapidly frozen in liquid nitrogen, and homogenized with ice-cold $0.5 \mathrm{~N}$ perchloric acid (PCA). Aliquots of each homogenate were neutralized for measurement of protein content and total radioactivity and the remainder was kept at $4{ }^{\circ} \mathrm{C}$ for $30 \mathrm{~min}$ before being centrifuged at $15000 \mathrm{~g}$ for $10 \mathrm{~min}$. The resulting pellets were washed once with $0.5 \mathrm{~N} \mathrm{PCA}$, and the pooled acid soluble fractions were treated with $0.83 \mathrm{~N} \mathrm{KOH}, 40 \mathrm{mM}$ tris- $\mathrm{HCl} \mathrm{pH}$ 8.3. After removal of potassium perchlorate by centrifugation, supernatants were frozen and stored at $-20^{\circ} \mathrm{C}$ for later use.

After measurement of the total radioactivity present in the soluble fractions their content of nucleotides and orotic acid was fractionated by two dimensional chromatography on thin layer PEI cellulose sheets using a modification of the method of Randerath and Randerath (1967). Origins were prespotted with marker solution containing uridylic and cytidylic nucleotides, orotic acid and uridine, the samples -were then applied. After preliminary development in distilled water, the dried sheets were developed in the same dimension with $1 \mathrm{M}$ acetic acid up to $8 \mathrm{~cm}$, then with $0.8 \mathrm{M} \mathrm{LiCl}$. After drying and desalting the chromatograms in anhydrous methanol, the second dimension was developed with three steps of formate buffer $\mathrm{pH} 4.3(0.5 \mathrm{M}$ $3 \mathrm{~s}, 2.0 \mathrm{M}$ for $2 \mathrm{~min}, 4.0 \mathrm{M}$ up to the top). Nucleotides and orotic acid were localised by ultraviolet light and spots were scraped for counting. Samples were counted in an 
Intertechnique liquid scintillation spectrometer and corrections for quenching and for incomplete separation of $\left({ }^{14} \mathrm{C}\right)$ and $\left({ }^{3} \mathrm{H}\right)$ spectra were applied.

Proteins were measured according to Lowry ef al. (1951) using bovine serum albumine as standard.

\section{Results.}

Quantitative incorporation of $\left({ }^{3} \mathrm{H}\right)$ orotic acid into RNA during regeneration.

Preliminary experiments established that exposure of simply decapitated planarians to $50 \mu \mathrm{Ci} / \mathrm{ml}$ of $\left({ }^{3} \mathrm{H}\right)$ orotic acid for periods as long as $24 \mathrm{hrs}$ did not result in sufficient labeling of the extracted RNA for accurate quantitative determination. Enhanced incorporation was obtained by increasing the number of activated zones in each planarian at which the RNA precursor was preferentially incorporated. Animals were therefore cut into six equal pieces, thus providing 10 blastema per planarian. These fragments of about $1 \mathrm{mn}$ were sufficient for survival and complete regeneration.

When planarians cut into six fragments were incubated with $\left({ }^{3} \mathrm{H}\right)$ orotic acid for 24 hrs either from 0 to $24 \mathrm{hrs}$ or from 24 to $48 \mathrm{hrs}$ after sectioning (results not shown), labelling of RNA was about seven times greater during the second day of regeneration than during the first. This incorporation was associated with an accumulation of newly synthesized RNA in the regenerating fragments since the total RNA extracted per planarian increased from 25 to $40 \mu \mathrm{g}$ between 0 and $48 \mathrm{hrs}$ after sectioning although the blastema was not yet developped and was composed of only a few cells at the 48th hr (Lender and Gabriel, 1960 ; Spiegelman and Dudley, 1973). Furthermore, the content of protein/animal did not change significantly during this period.

To elucidate the events underlying enhanced RNA labeling during the second as compared to the first day of regeneration, the time course of RNA synthesis and the type of RNA synthesised were investigated. Figure 1 shows the variation with time of the specific activity of RNA extracted after incubation of planarian fragments in the presence of $50 \mu \mathrm{Ci} / \mathrm{ml}$ of $\left({ }^{3} \mathrm{H}\right)$ orotic acid for $2 \mathrm{hrs}$. By comparison with intact animals (time 0 ) incorporation of labeled precursor into RNA of regenerating planarian fragments was stimulated only from the $7 \mathrm{th} \mathrm{hr}$ after sectioning. The rate of $\left({ }^{3} \mathrm{H}\right)$ orotic acid incorporation into RNA reached a maximum at $18 \mathrm{hrs}$, fell sharply for the following $3 \mathrm{hrs}$, and then increased again until $30 \mathrm{hrs}$ after sectioning. Subsequently, a progressive decrease occurred up to the 7th day or regeneration Comparison of the incorporation of $\left({ }^{3} \mathrm{H}\right)$ orotic acid and of guanosine $\left({ }^{14} \mathrm{C}\right)$ RNA precursor which are metabolised to nucleotides triphosphates by completely different metabolic pathways (Hauschka, 1973) showed that these variations of RNA labeling were independent of the nature of the labeled precursor used.

These observations suggested that the pattern of RNA labeling during planarian regeneration reflected variations in the rate of RNA synthesis. If this is the case, the specific activities of the pools of nucleotide precursors would remain more or less constant. We used the following double labeling technique in order to test the accuracy of this hypothesis at the crucial period of transition between the first and the second phase of RNA labeling. 


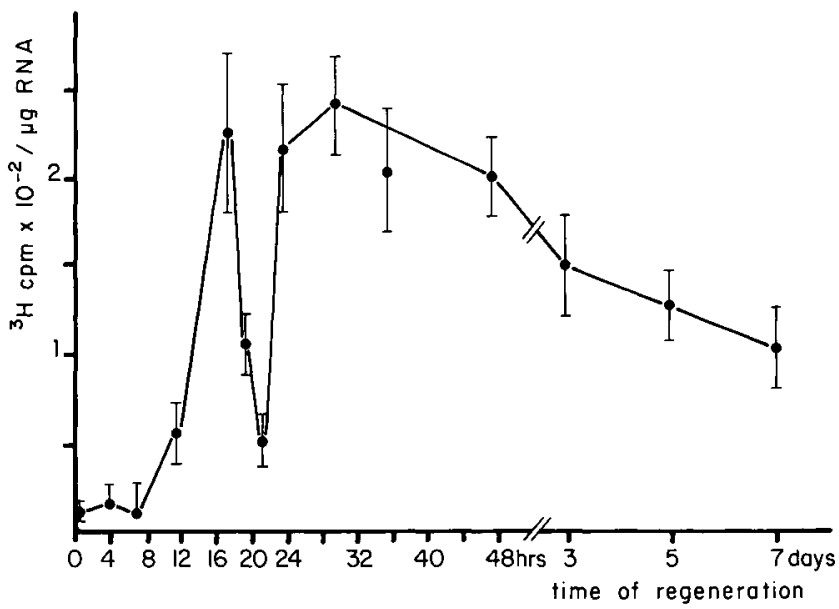

FIG. 1. - Rote of incorporation of $\left({ }^{3} \mathrm{H}\right)$ orotic acid into RNA during planarian regeneration. RNA was extracted from regenerating animals which had been incubated for $2 \mathrm{hrs}$ with $\left({ }^{3} \mathrm{H}\right)$ orotic acid $(50 \mu \mathrm{Ci} / \mathrm{ml})$ at various times during the regeneration process. Each point represents the mean of 6 to 12 independent measurements. Error bars represent confidence intervals for $p<0.05$. Each measurement was performed with two planarians.

\section{Study of the labeling of the nucleotide pool.}

The intracellular nucleotide pool was equilibrated with $\left({ }^{14} \mathrm{C}\right)$ orotic acid for $30 \mathrm{hrs}$ prior to sectioning the animals. After 16,19 and $22 \mathrm{hrs}$ of regeneration in tap-water, a $2 \mathrm{hr}$-pulse with $\left({ }^{3} \mathrm{H}\right)$ orotic acid was applied. The amounts of labelled orotic acid and of uridylic and cytidylic nucleotides in the acid soluble pool were then determined (table 1). As measured by the ratio of the amounts of each isotope found in the pools of

TABLE 1

Composition of the acid soluble fractions of intact and regenerating planarians

\begin{tabular}{|c|c|c|c|c|c|c|c|c|c|c|c|c|}
\hline \multirow[b]{4}{*}{$\begin{array}{l}\text { UTP }+ \text { UDP }+ \\
\text { UMP } \ldots \ldots \ldots\end{array}$} & & & & \multicolumn{9}{|c|}{ Hours of regeneration } \\
\hline & \multicolumn{3}{|c|}{ Intact planarians } & \multicolumn{3}{|c|}{18} & \multicolumn{3}{|c|}{21} & \multicolumn{3}{|c|}{24} \\
\hline & ${ }^{3} \mathrm{H}$ & ${ }^{14} \mathrm{C}$ & ${ }^{3} \mathrm{H} /{ }^{14} \mathrm{C}$ & ${ }^{3} \mathrm{H}$ & ${ }^{14} \mathrm{C}$ & ${ }^{3} \mathrm{H} /{ }^{14} \mathrm{C}$ & ${ }^{3} \mathrm{H}$ & ${ }^{14} \mathrm{C}$ & ${ }^{3} \mathrm{H} /{ }^{14} \mathrm{C}$ & ${ }^{3} \mathrm{H}$ & ${ }^{14} \mathrm{C}$ & ${ }^{3} \mathrm{H} /{ }^{4} \mathrm{C}$ \\
\hline & 2210 & 1083 & 2.04 & 3105 & 900 & 3.45 & 2651 & 775 & 3.42 & 3780 & 852 & 4.44 \\
\hline $\begin{array}{l}\text { CTP }+ \text { CDP }+ \\
\text { CMP } \ldots \ldots \ldots\end{array}$ & 774 & 231 & 3.35 & 1162 & 178 & 6.53 & 1470 & 160 & 9.19 & 1708 & 216 & 7.91 \\
\hline Orotic acid $\quad \ldots$. & 6201 & 237 & 26.16 & 31305 & 168 & 186.33 & 17184 & 96 & 179 & 10564 & 84 & 12576 \\
\hline
\end{tabular}

The amounts of labelled uridylic and cytidylic nucleotides and orotic acid in the acid soluble fraction of planarians were determined by PEI cellulose thin layer chromatography.

The results, given in $\mathrm{dpm} /$ planarian represent the mean of two independent determinations. 
uridylic and cytidylic nucleotides (on average, 4.6 for $\left({ }^{14} \mathrm{C}\right)$ and 2.4 for $\left({ }^{3} \mathrm{H}\right)$ ) the ,metabolism of orotic acid into the nucleotides did not differ markedly at various time of regeneration. Furthermore, the $\left({ }^{3} \mathrm{H}\right) /\left({ }^{14} \mathrm{C}\right)$ of each group of nucleotides did not display significative variations between 18 and $24 \mathrm{hrs}$ of regeneration in spite of extensive changes in free $\left({ }^{3} \mathrm{H}\right)$ orotic acid content. Therefore, the varying penetration of exogenous $\left({ }^{3} \mathrm{H}\right)$ orotic acid into sectioned planarians seems to be balanced by a mechanism of regulation which controls its transformation into the final nucleotides.

The results indicated that the reduced labeling of RNA between 18 and 21 hrs after sectioning and the subsequent rise at the 24 th reflected actual variations in RNA synthesis rather than variations in the labeling of the pool of nucleotide precursors.

\section{Qualitative studies of extracted RNA.}

In order to compare the amounts of different classes of RNA synthesized during regeneration, RNA samples prepared at different times after sectioning were analysed by polyacrylamide gel electrophoresis. Results representative of the two phases of regeneration are shown in figure 2. The p. 100 of total input radioactivity found in various size classes of RNA at different times of regeneration was then calculated (table 2).

It is noteworthy that a $2 \mathrm{hr}$-labeling period was sufficient for completion of the synthesis of mature rRNA in the regenerating planarians. The molecular weights assigned to $r$ RNA were $1.53 \times 10^{6} \quad(S E M=0,02 ; n=25)$. And $0.76 \times 10^{6}$ $(S E M=0.01 ; n=25)$. The small additional peaks of labelled RNA corresponding to $3.8 \times 10^{6}$ and $1.75 \times 10^{6}$ daltons may represent rRNA precursors.

Extracts from unsectioned animals (fig. $2 a$ ) or planarians cut into six fragments which had regenerated for 4 hrs displayed a rather low and unspecific background of
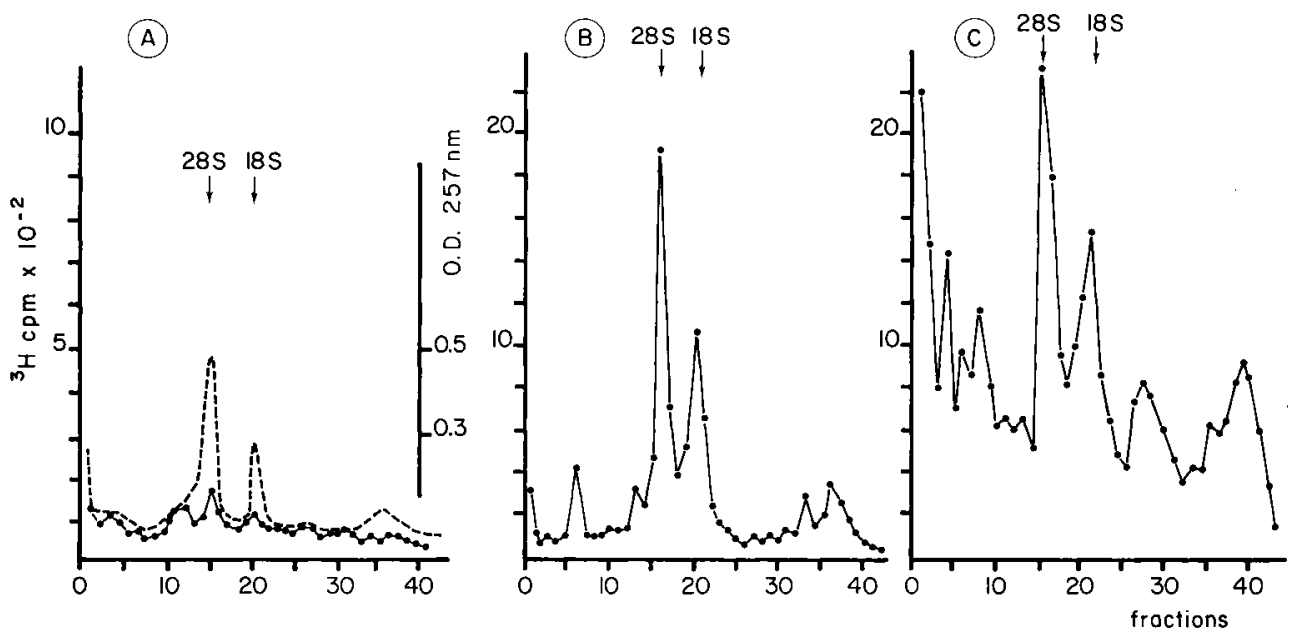

FIG. 2. - Electrophoresis of total RNA extracted from infact planarians or sectioned animals after regeneration for 18 and 24 hrs. Animals were incubated with $\left({ }^{3} \mathrm{H}\right)$ orotic acid for 2 hrs before extraction of the total RNA : - - O. D. at $257 \mathrm{~nm},-\longrightarrow$ radioactivity in $2 \mathrm{~mm}$ slices ; A : intact planarians $38 \mu \mathrm{g}$ of RNA ; B : 18 hrs of regeneration, $22 \mu \mathrm{g}$ of RNA ; C : 24 hrs of regeneration, $20.5 \mu \mathrm{g}$ of RNA. 
TABLE 2

Distribution of labeled RNA at different stages of regeneration in terms of molecular weight

Time of regeneration

Molecular weight

\begin{tabular}{cccc}
$>1.7 .10^{6}$ & $1.7 .10^{6}-0.7 .10^{6}$ & $0.70 .10^{6}-0.3 .10^{6}$ & $<0.3 .10^{6}$ \\
\hline 17.2 & 61.5 & 9.0 & 12.2 \\
$(16.0-18.4)$ & $(59.2-63.8)$ & $(8.6-9.4)$ & $(11.5-12.9)$ \\
155.9 & 58.7 & 15.7 & 15.0 \\
$(14.3-18.5)$ & $(54.0-63.1)$ & $(8.3-11.8)$ & $(14.0-15.7)$ \\
18.3 & 53.2 & 13.8 & 14.9 \\
$(15.2-21.4)$ & $(52.1-54.2)$ & $(12.7-4.2)$ & $(14.0-15.8)$ \\
26.6 & 43.1 & 15.2 & 15.1 \\
$(25.7-27.5)$ & $(41.9-44.3)$ & $(15.0-15.4)$ & $(14.0-15.8)$ \\
39.1 & 30.4 & 15.5 & 15.1 \\
$(35.6-42.6)$ & $(27.4-35.3)$ & $(12.3-16.5)$ & $(14.1-16.1)$ \\
35.0 & 34.2 & 15.0 & 16.6 \\
$(33.6-36.4)$ & $(33.5-34.9)$ & $(14.1-15.9)$ & $(15.1-17.1)$ \\
31.2 & 38.0 & 13.6 & 17.5 \\
$(28.5-33.9)$ & $(35.2-40.8)$ & $(12.7-14.5)$ & $(16.5-18.5)$ \\
31.2 & 44.7 & 11.2 & 13.0 \\
$(28.2-34.2)$ & $(41.0-48.4)$ & $(10.2-12.2)$ & $(12.5-13.5)$ \\
19.6 & 62.5 & 6.2 & 11.7 \\
$(18.1-21.1)$ & $(60.5-64.5)$ & $(5.7-6.7)$ & $(10.2-13.2)$ \\
& & & \\
\hline
\end{tabular}

Electrophoretic distribution profiles of labelled RNA obtained at different times of regeneration after sectioning, were divided into four molecular weight classes as indicated and the p. 100 of labeled RNA in each class was calculated. The mean, and the range in brackets are given. Data at 18, 21 and $24 \mathrm{hrs}$ were obtained in four different experiments, two determinations were performed for the other periods of regeneration.

labelled RNA after a $2 \mathrm{hr}$-pulse. A $24 \mathrm{hr}$-pulse of intact planarians was in fact necessary for the localization of rRNA and low molecular weight RNA in an electrophoretic pattern (Martelly ef al., 1976). Only ribosomal RNA species and low molecular weight RNA were detected in extracts of regenerating animals pulsed after 12 hrs of regeneration and the pattern seen at $18 \mathrm{hrs}$ was not significantly different from observed at $12 \mathrm{hrs}$. On the other hand, the $24 \mathrm{hr}$ samples displayed a more heterogeneous pattern of RNA species ranging from $3.5 \times 10^{6}$ to $0.3 \times 10^{6}$ daltons. This heterogeneity of RNA species persisted in the 36 an $46 \mathrm{hr}$ samples but was reduced after $72 \mathrm{hrs}$ at which time rRNA again became predominent. The proportion of low molecular weight RNA rose from 12 to 17 p. 100 befween 12 and 36 hrs and subsequently fell to about 12 p. 100 at $72 \mathrm{hrs}$ (table 2).

\section{Discussion.}

Planarians have been extensively used for investigation of Invertebrate regeneration. However, biochemical studies in the field are rather fragmentary and up to now, no quantitative study of RNA synthesis during regeneration has been carried out. We report here a simple procedure which enabled us to undertake such a study using small quantities of material present in a few planarians or even a single animal, whereas earlier reports on RNA studies required several hundred animals (Stewart ef al., 1969 ; Gabriel, 1968b). 
In regenerating adult planarians, incorporation of labeled orotic acid into RNA showed a biphasic pattern. The first phase lasted up to the $21 \mathrm{st}$ hr after sectioning, and was followed by a second which lasted from 24 hrs after sectioning until completion of regeneration. The observed variation of incorporation of orotic acid into RNA reflected variations of RNA synthesis. Indeed, the results of measurements of the size of pools of nucleotide precursors obtained by a double labeling technique (table 1) exclude possible effects of fluctuating metabolism of orotic acid into nucleotides on the incorporation of the labeled products into RNA. It is noteworthy that the penetration of exogeneous orotic acid varied with the time of regeneration. It is therefore possible that the impairement of precursor uptake observed at the $21 \mathrm{st}$ hr of regeneration could be a manifestation of an end-product inhibition induced by a decreased rate of nucleic acid synthesis and consequently, a decreased rate of removal of precursors from the available pools. Such an occurrence has been reported in actinomycin $D$ treated cells (Skehel ef al., 1967). On the contrary, the increased uptake of orotic acid at $24 \mathrm{hrs}$ would be caused by an elevating increased rate of RNA synthesis.

In other experiments we have studied the kinetics of RNA labeling after the 18 th $\mathrm{hr}$ of regeneration under pulse and chase conditions in the presence or absence of actinomycin D (unpublished results). In such experiments, a reduction of RNA labeling was observed after a chase and this effect was increased in the presence of actinomycin D, suggesting that degradation of RNA may occur after the 18 th $\mathrm{hr}$ after sectioning simultaneously with a reduced rate of RNA synthesis.

Electrophoretic analyses of RNA labelled for 2 hrs at various times during planarian regeneration showed that at early times after sectioning rRNA was the major product formed and that large amounts of polydisperse RNA were also formed at the beginning of the second phase of RNA synthesis. Although we cannot exclude the possibility that some RNA, in particular mRNA may be lost in the course of extraction, all experiments were performed under similar conditions and we therefore, conclude that changes in the content of polydisperse RNA reflect physiological differences in the course of planarian regeneration. Moreover, the initial stimulation of rRNA synthesis is consistent with the morphological observations in which the first signs of cellular activation after the sectioning were the appearance of activated nucleoli and of an increased number of cytoplasmic ribosomes in the undifferenciated cells (Morita et al., 1969 ; Spiegelman and Dudley, 1973 ; Sauzin-Monnot, 1975). Stimulation of rRNA synthesis at the onset of a regeneration process has also been reported in particular in lens (Reese ef al., 1969) and limb (Morzlock and Stocum, 1971) regeneration in Triturus viridescens.

It has been reported that actinomycin $D$ completly prevented regeneration when applied during the first day after sectioning (Gabriel, 1969 ; Le Moigne and Martelly, 1974). Impairment of the regeneration process by inhibition of RNA synthesis decreased when the inhibitor was present from the 24th hr following sectioning. After $48 \mathrm{hr}$ of regeneration the process was no longer affected by actinomycin $D$. These results suggested that mRNA produced during the first phase of regeneration was not sufficient for the development of the blastema and its differentiation and that the second phase of RNA synthesis must be initiated for completion of regeneration.

A biphasic pattern of $\left({ }^{3} \mathrm{H}\right)$ uridine incorporation into RNA has also been reported in the course of regeneration of the oligochete Eisenia foetida (Lechenault and Gont- 
charoff, 1972) and the polychete Owenia fusiformis (Thouveny ef al., 1972, Fontes et al., 1979). In the former case, the first peak of RNA was composed principally of polydisperse and low molecular weight RNA whereas the second peak predominantly contained rRNA. A short peak of protein synthesis was observed before the onset of the stimulation of RNA synthesis. These primary peaks of RNA and protein corresponded to the period of cellular activation and dedifferentiation which occured in the regeneration of Annelids. In planarians, where a dedifferentiation phase has not been established, the onset of the regeneration process seems to be characterized by a different time course of synthesis of the different RNA species.

Variations of CAMP content during planarian regeneration have been reported (Franquinet and Le Moigne, 1979) and their comparison with the pattern of RNA synthesis, during regeneration strongly suggests a negative control of the transcription level by the cyclic nucleotide. Such a process was reported for example in Wolffian lens regeneration (Thorpe et al., 1974). Experiments are now in progress to analyse the effect on RNA synthesis of CAMP or neuromediators (or their antagonists) which modify directly or indirectly the cAMP content (Franquinet and Martelly, in preparation).

Reçu en janvier 1980.

Accepté en avril 1980.

Acknowledgements. - The technical assistance of Miss C. Borney is gratefully acknowledged. We are grateful to Dr. J. Chapman and Dr. J. L. Montagnier for reading and discussing the paper, to Drs. S. Nocentini and J. Hanoune for technical advice and to Unit 99 INSERM for the provision of counting.

Résumé. Une méthode d'extraction des ARN totaux adaptée aux planaires a été appliquée à l'étude des synthèses d'ARN chez ces animaux au cours de la régénération. Ces synthèses sont stimulées en deux phases. La première phase est caractérisée par une augmentation de l'incorporation de l'acide orotique $\left({ }^{3} \mathrm{H}\right)$ entre 7 et $18 \mathrm{~h}$ après la section suivie par une diminution jusqu'à la $21 \mathrm{e} \mathrm{h}$. L'incorporation du précurseur augmente à nouveau jusqu'à $30 \mathrm{~h}$, reste à un niveau élevé plusieurs jours et décroît lentement à la fin de la régénération. Ces variations d'incorporation du précurseur dans les ARN semblent refléter des variations de synthèses d'ARN puisque le marquage du pool de nucléotides ne change pas significativement. Au cours de la première phase des synthèses d'ARN, on détecte essentiellement des ARN ribosomaux et des $A R N$ de poids moléculaire légers, alors que au cours de la seconde phase, outre ces ARN, on décèle également des ARN de poids moléculaire hétérogènes jusqu'au $3^{\mathrm{e}}$ jour de régénération. Les $\mathrm{ARN}$ ribosomaux redeviennent ensuite prédominants. La signification de ces deux phases du métabolisme des ARN est discutée en rapport avec d'autres événements biochimiques décrits au cours de la régénération des planaires ou d'autres animaux.

\section{References}

BISHOP D. H. L., CLAYBROOK J. R., SPIEGELMAN S., 1967. Electrophoretic separation of viral nucleic acids on polyacrylamide gels. J. mol. Biol., 26, 373-387.

BRONDSTED H. V., 1969. Biochemical investigations on planarian regeneration, 183-198. In : Planarian regeneration, Pergamon Press. 
BRAWERMAN G., 1973. The isolation of RNA from mammalian cell, 1-22. In Methods in cell biology, vol. VII. Acad. Press.

FONTES M., RAILHAC C., THOUVENY Y., 1979. Pattern of RNA synthesis during the regeneration by Owenia foetida (polychete annelid). Biochimie, 61, 369-377.

FRANQUINET R., LE MOIGNE A., 1979. Relation entre les variations de sérotonine ef d'AMP cyclique au cours de la régénération d'une planaire. Biol. cell., 34, 71-76.

GABRIEL A., 1968a. Influence du moment de l'irradiation aux rayons $X$ sur la régénération ef le taux d'incorporation de l'uridine tritiée chez la Planaire Dugesia gonocephala (Turbellarié Triclade). C. R. Acad. Sci. Paris, Sér. D, 266, 820-822.

GABRIEL A., 1968b. Action de l'actinomycine D sur la régénération ef le métabolisme de l'acide ribonucléique chez la planaire Dugesia gonocephala (Turbellarié Triclade). C. R. Acad. Sci. Paris, Sér. D, 266, 406-409.

GABRIEL A. 1969. Etude morphologique ef évolution biochimique des néoblastes au cours des premières phases de la régénération des planaires d'eau douce. Ann. Embr. Morph., 3, 49-69.

HAUSCHKA P. V., 1973. Analysis of nucleotide pools in animal cells, 361-462. In Methods in cell biology, vol. VII. Acad. Press.

HORISBERGER M., AMOS H., 1970. Ribonucleic synthesis and transport in animal cells at $27^{\circ} \mathrm{C}$. Biochem. J., 117, 347-353.

LECHENAULT H., GONTCHAROFF M., 1973. Le métabolisme des acides nucléiques et des protéines au cours des six premiers jours de la régénération céphalique d'Eisenia foetide (Sav.). Wilhem Roux'Archiv., 173, 60-76.

LE MOIGNE A., MARTELLY I., 1974. Effet de l'emploi préventif ou différé de l'actinomycine D sur la régénération de planaires jeunes et adultes. C. R. Acad. Sci. Paris, Sér. D, 279, 367-369.

LENDER T., GABRIEL A., 1960. Sur la répartition des néoblastes de Dugesia lugubris avant ef pendant la régénération. C. R. Acad. Sci. Paris, Sér. D, 250, 2465-2467.

LOENING U. E., 1967. The fractionation of high molecular-weight ribonucleic acid by polyacrilamide gel electrophoresis. Biochem. J., 102, 251-257.

LOWRY O. H., ROSEBROUGH J. N., FARR A. L., RANDALL R. J., 1951. Protein measurement with the folin-phenol reagent. J. biol. Chem., 193, 265-275.

MARTELLY I., BORNEY C., LE MOIGNE A., 1976. Mise en évidence de deux phases dans les synthèses d'ARN au cours de la régénération de la planaire (Polycellis fenuis nigra), C.R.Acad. Sci. Paris, Sér. D, 282, 1805-1808.

MORITA M., BEST J. B., NOEL J., 1969. Electronmicroscopic studies of planarian regeneration. 1. Fine structure of neoblasts in Dugesia dorotocephala. J. ultrastr. Res., 27, 7-23.

MORZLOCK F. V., STOCUM D. L., 1971. Patterns of RNA synthesis in regenerating limbs of the adult newt Triturus viridescens. Develop. Biol., 24, 106-188.

POULSON R., 1973. Isolation, purification and fractionation of RNA, 243-261. In P. R. STEWARD, D. S. LETHAM : The ribonucleic acids. Springer-Verlag.

RANDERATH K., RANDERATH E., 1967. Thin layer separation methods for nucleic acid derivates. In Methods in Enzymology, vol. 12 A, 323-347.

REESE D. H., PUCCIA E., YAMADA T., 1969. Activation of ribosomal RNA synthesis in initiation of wolffian lens regeneration. J. exp. Zool., 170, 259-268.

SAUZIN M. J., 1967a. Etude ultrastructurale de la différenciation du néoblaste au cours de la régénération de la planaire Dugesia gonocephala : I. - Différenciation en cellule nerveuse. Bull. Soc. Zool. Fr., 92, 313-318.

SAUZIN M. J., 1967b. Etude structurale de la différenciation du néoblaste au cours de la régénération de la planaire Dugesia gonocephala : II. - Différenciation musculaire. Bull. Soc. Zool. Fr., 92, 613-616.

SAUZIN-MONNOT M. J., 1973. Etude ultrastructurale des néoblastes de Dendrocoelum lacteum au cours de la régénération. J. ultrastruc. Res., 45, 206-222.

SAUZIN-MONNOT M. J., 1975. La régénération des planaires d'eau douce. Efude ultrastructurale des premières étapes, influence du système nerveux. Th. Doct., Univ. Paris XI, Orsay, France.

SENGEL C., 1960. .Culture in vitro de blastèmes de régénération de planaires. J. Embryol. exp. Morph., 8, 468-476.

SKEHEL J. J., HAY A. J., BURKE D. C., CARTWRIGHT L. N., 1967. Effects of actinomycin D and 2-mercapto-1-(4-pyridethyl-benzimidazol) on the incorporation of $\left({ }^{3} \mathrm{H}\right)$ uridine by chick embryo cells. Biochim. biophys. Acta, 142, 430-439. 
SPIEGELMAN M., DUDLEY P. L., 1973. Morphological stages of regeneration in the planarian Dugesia tigrina: A light and electron microscopic study. J. Morph., 139, 155-184.

STANLEY W. M., BOCK R. M., 1965. Isolation and physical properties of the ribosomal ribonucleic acid of Escherichia coli. Biochemistry, 4, 1302-1311.

STEWART K., GOODMAN A. B., BEST J. B., 1968. RNA composition of the planarian Dugesia dorotocephala. J. exp. Zool., 169, 9-14.

THORPE C. W., BOND J. S., COLLINS J. H., 1974. Early events in lens regeneration : changes in cyclic AMP concentrations during initiation of RNA and DNA synthesis. Biochim. biophys. Acta, 340, 413-418.

THOUVENY Y., COULON J., FONTES M., 1972. Ełude biochimique et cytologique de la différenciation cellulaire dans la régénération antérieure de l'Annélide Owenia fusiformis (Delle Chiaje). Bull. Soc. Zool. Fr., 97, 311-326. 